\title{
HUBUNGAN POLA MAKAN DAN TINGKAT STRES DENGAN KEJADIAN DISPEPSIA DI RUMAH SAKIT UMUM SUNDARI MEDAN TAHUN 2019
}

\author{
Muflih, Najamuddin \\ Program Studi D-III Keperawatan, Institut Kesehatan Helvetia \\ E-mail : muflihop@helvetia.ac.id
}

\begin{abstract}
Dyspepsia is a collection of symptoms in the form of complaints of pain, unpleasant feelings in the upper gastrointestinal tract. The prevalence of dyspepsia globally in the world is between 7-45\%. The prevalence of dyspepsia in the United States is $23-25.8 \%$, India $30.4 \%$, Hong Kong $18.4 \%$, Australia 24.4-38.2\%, and China 23.3\%. The research objective was to determine the relationship between diet and stress levels with the incidence of dyspepsia in the Sundari General Hospital in Medan in 2019. The design of this study was an analytical survey research design that contained descriptions. The population in this study were 54 people and the sampling method in this study was using accidental sampling by accident without planning. Whoever is there is assigned a sample of 41 people. Data collection methods are primary data, secondary data and tertiary data. The data analysis used was the Chi-square test. The results showed that the perception has a value of $\alpha=$ 0.05 , and the value of $p=0.020<$ from $\alpha=0.05$ is obtained. Then it is obtained that there is a relationship between diet and the incidence of dyspepsia in the Sundari Medan General Hospital in 2019 and stress levels with the incidence of dyspepsia with a value of $\alpha=0.05$, the value of $p=$ $0.038<$ from $\alpha=0.05$ is obtained. So it is obtained that there is a relationship between stress levels and the incidence of dyspepsia in the Sundari Medan General Hospital in 2019. The conclusion in this study is that there is a relationship between diet and stress levels with the incidence of dyspepsia in Sundari General Hospital Medan in 2019. It is recommended that this research be used as input. and consideration for dyspepsia sufferers so that dyspepsia patients in Sundari hospital are reduced.
\end{abstract}

Keywords : Diet, Stress Level, Dyspepsia

\begin{abstract}
Abstrak
Dispepsia merupakan kumpulan gejala berupa keluhan nyeri, perasaan tidak enak pada saluran pencarnaan bagian atas. Prevalensi dispepsia secara global di dunia antara 7-45\%. Prevalensi dispepsia di Amerika Serikat 23-25,8\%, India 30,4\%, Hongkong 18,4\%, Australia 24,4-38,2\%, dan China sebesar 23,3\%. Tujuan penelitian untuk mengetahui hubungan pola makan dan tingkat stres dengan kejadian dispepsia di Rumah Sakit Umum Sundari Medan tahun 2019. Desain penelitian ini merupakan desain penelitian survey analitik yang berisi urain-uraian. Populasi dalam penelitian ini sebanyak 54 orang dan cara pengambilan sampel dalam penelitian ini dengan menggunakan accidental sampling dengan cara kebetulan tanpa direncanakan. Siapa saja yang ada di tetapkan menjadi sampel yang berjumlah sebanyak 41 orang. Metode pengumpulan data yaitu data primer, data sekunder dan data tertier. Analisis data yang digunakan dengan uji Chi-square. Hasil penelitian menunjukkan persepsi memiliki nilai $\alpha=0,05$ diperoleh nilai $p=0,020<$ dari $\alpha=$ 0,05. Maka diperoleh ada hubungan pola makan dengan kejadian dispepsia di Rumah Sakit Umum Sundari Medan tahun 2019 dan tingkat stres dengan kejadian dispepsia nilai $\alpha=0,05$ diperoleh nilai $p=0,038<$ dari $\alpha=0,05$. Maka diperoleh ada hubungan tingkat stres dengan kejadian dispepsia di rumah sakit umum sundari Medan tahun 2019. Kesimpulan dalam penelitian ini ada hubungan antara pola makan dan tingkat stres dengan kejadian dispepsia di Rumah Sakit Umum Sundari Medan tahun 2019. Disarankan penelitian ini dapat dijadikan sebagai bahan masukan dan
\end{abstract}


pertimbangan kepeda penderita dispepsia sehingga penderita dispepsia di rumah sakit sundari berkurang.

Kata Kunci : Pola Makan, Tingkat Stres, Dispepsia

\section{PENDAHULUAN}

Pola makan adalah susunan jenis dan jumlah makanan yang di konsumsi seseorang atau sekelompok orang pada waktu tertentu terdiri dari frekuensi makan, jenis makanan, dan porsi makan. Dalam penelitian Sulastri jumlah dan frekuensi makan perlu di perhatikan untuk meringankan pekerjaan saluran pencernaan dimana sebaiknya makan tiga kali sehari dalam porsi kecil. Jenis makanan perlu juga diperhatikan agar tidak merusak lapisan mukosa lambung.

Kebiasaan makan adalah istilah yang digunakan untuk menggambarkan pola makan yang teratur dan tidak teratur yang dapat mempengaruhi resiko terjadinya dyspepsia (Haryono, 2012).

Gizi seimbang adalah jumlah gizi sesuai dengan kebutuhan, selain itu setiap orang memerlukan berbagai jenis makanan karena tidak semua zat gizi ada didalam satu makanan yang dibutuhkan tubuh. Gizi seimbang tidak hanya berkaitan denagn jenis makanan.

Dispepsia adalah rasa nyeri atau tidak nyaman di bagian ulu hati. Dispepsia meliputi kumpulan gejala klinis yang terdiri dari rasa tidak nyaman atau sakit menetap atau mengalami kekambuhan pada perut bagian atas. Keluhan akan gejala-gejala klinis tersebut kadang-kadang disertai dengan rasa panas di dada dan perut, rasa lekas kenyang, anoreksia, kembung, regurgitasi, dan banyak mengeluarkan gas asam dari mulut (Iman, 2016)

Dispe psia dapat dipengaruhi oleh beberapa faktor, diantaranya adalah meningkatnya sekresi asam lambung, faktor diet dan lingkungan, serta faktor psikologi seperti stres (Perwitasari, 2016).

Perubahan pola makan yang tidak teratur, obat-obatan yang tidak jelas, zat-zat seperti nikotin dan alkohol serta adanya kondisi kejiwaan stres, pemasukan makanan menjadi kurang sehingga lambung akan kosong, kekosongan lambung dapat mengakibatkan erosi pada lambung akibat gesekan antara dinding-dinding lambung. Kondisi demikian dapat mengakibatkan peningkatan produksi HCL yang akan merangsang terjadinya kondisi asam pada lambung sehingga rangsangan di medulla oblongata membawa impuls muntah sehingga intake tidak adekuat baik makanan maupun cairan (Nurul, 2018).

Stres merupakan respon tubuh yang sifatnya non spesifik terhadap setiap tuntutan beban atasnya. Stres yaitu mengacu pada pristiwa yang dirasakan membahayakan kesejahteraan fisik dan psikologis seseorang. Stres memiliki efek negatif melalui mekanisme neuroendokrin terhadap saluran pencernaan sehingga beresiko untuk mengalami dispepsia. Produksi asam lambung akan meningkat pada keadaan stres, misalnya pada beban kerja berat dan tergesagesa/pani (Widiya, 2017).

Stres dalam arti secara umum adalah perasaan tertekan, cemas, dan tegang. Dalam bahasa sehari-hari stres di kenal sebagai stimulis atau respon yang menuntut individu untuk melakukan penyesuaian. Serafino mengartikan stres alalah kondisi yang di sebabkan oleh interaksi antara individu dengan lingkungan, menimbulkan persepsi jarak antara tuntutan-tuntutan yang berasal dari situasi yang bersumber pada sistem biologis, psikologis dan sosisal seseorang (Ariwibowo, 2012).

Dispepsia merupakan kumpulan gejala berupa keluhan nyeri, perasaan tidak enak pada saluran pencarnaan bagian atas, yang menetap atau episodic disertai dengan keluhan seperti rasa penuh saat makan, cepat kenyang, heartburn, kembung, sendawa, mual dan muntah. Penyebab timbulnya dispepsia di antaranya adalah faktor meningkatnya sekresi asam lambung, fungsi motorik lambung, dan infeksi Helicobacter pylori (sorongan, 2013) 
Dispepsia merupakan gangguan yang kompleks, mengacu pada kumpulan gejala seperti sensasi nyeri atau tidak nyaman di perut bagian atas, terbakar, mual muntah, penuh dan kembung. Berbagai mekanisme yang mungkin mendasari meliputi gangguan motilitas usus, hiper sensitivitas, infeksi, ataupun faktor psikososial (Purnamasari, 2017)

Pencegahan dispepsia menurut Iman (2016) yaitu : 1) Pola makan yang normal dan teratur. Pilih makanan yang seimbang dengan kebutuhan dan jadwal makan yang teratur, tidak mengkonsumsi makanan yang berkadar asam tinggi, makanan pedas, makanan/minuman yang mengandung alkohol, dan berhenti merokok. Gunakan obat secara wajar dan tidak mengganggufungsi lambung. 2) Hindari makan bakmi berlebihan, khususnya dalam keadaan perut kosong karena air abu yang menguningkan bakmi sangat tajam bagi lambung.

Prevalensi dispepsia secara global di dunia antara 7-45\%. Prevalensi dispepsia di Amerika Serikat 23-25,8\%, India $30,4 \%$, Hongkong $18,4 \%$, Australia 24,4$38,2 \%$, dan China sebesar 23,3\%. (Purnamasari, 2017). Prevalensi dispepsia di Asia Pasifik sekitar 10-20\% juga merupakan keluhan yang banyak dijumpai (Jaji, 2016). Data Profil Kesehatan Indonesia, dispepsia menempati peringkat ke-10 untuk kategori penyakit terbanyak pasien rawat inap di Rumah Sakit dengan jumlah pasien 34.029 atau sekitar 1,59\%. Sindroma dispepsia dapat di klasifikasikan berdasarkan penyebabnya yaitu sindroma dispepsia akibat kelainan organik dan sindroma dispepsia fungsional (non-organik) (Putri, 2015).

Hasil penelitian Nurul Afifah yang dilakukan pada tanggal 11 Oktober 2017 di Universitas Aisyiyah Yogyakarta pada mahasiswa ilmu keperawatan semester delapan didapatkan data bahwa 75\% mahasiswa pernah mengalami keluhan berupa nyeri atau tidak rasa nyaman pada ulu hati, mual, kembung, muntah, sendawa, rasa cepat kenyang, dan perut terasa penuh sehingga mengganggu aktivitas mereka.
Sebabyak 65,5\%,Sebagian dari mereka mengatakan sering mengabaikan pola makan dengan alasan padatnya jadwal perkuliahan dan sibuk memikirkan skiripsi (Tiana, 2017).

Berdasarkan hasil survei awal di Rumah Sakit Umum Sundari Medan Tahun 2019 yang menderita penyakit dispepsia, penderita dispepsia terhitung dari bulan Juli sampai dengan Desember tahun 2018 berjumlah 224 orang. Penderita dispepsia pada laki-laki mulai dari umur 15-70 tahun terdapat 138 orang yang terkena penyakit dispepsia, dan jumlah perempuan terdapat 86 orang yang terkena penyakit dispepsia. Pada tahun 2019 terhitung dari bulan Februari sampai dengan April terdapat 23 orang jumlah laki-laki dan 31 orang jumlah perempuan yang terkena penyakit dispepsia. Berdasarkan hasil survei awal saya diatas, saya tertarik untuk mengambil judul ini dan tempat penelitiannya di Rumah Sakit Umum Sundari Medan.

\section{METODE PENELITIAN}

Desain penelitian ini merupakan desain penelitian survey analitik yang berisi urain-uraian. Dengan pendekatan cross sectional yang mencoba menggali bagaimana dan mengapa fenomena itu terjadi, yang bertujuan untuk mengetahui Hubungan Pola Makan Dan Tingkat Stres Dengan Kejadian Dispepsia Di Rumah Sakit Umum Sundari Medan Tahun 2019. Lokasi yang menjadi tempat penelitian adalah di di Rumah Sakit Umum Sundari Medan. Waktu yang diperlukan untuk penelitian ini dimulai dari bulan Februari-Juni tahun 2019. Populasi adalah keseluruhan dari objek penelitian atau objek yang di teliti. Populasi yang diambil dalam penelitian ini adalah laki-laki dan wanita yang mengalami dispepsia di Rumah Sakit Umum Sundari Medan pada bulan Februari sampai dengan bulan April Tahun 2019 sebanyak 54 orang populasi. Peneliti menggunakan tehnik sampel (Accidental Sampling), yaitu pengambilan sampel secara kebetulan tanpa direncanakan. Siapa saja yang ada di tetapkan menjadi sampel yang berjumlah sebanyak 41 orang. Dalam penelitian ini peneliti menetapkan sampelnya 
sebanyak 41 orang, dikarenakan ada 13 orang sampel yang menolak untuk ikut dalam penelitian ini dan peneliti tidak berhak mengikut sertakan bagi sampel yang menolak dalam terwujudnya penelitian ini (Tilong, 2014).

HASIL PENELITIAN

Karakteristik Responden

Tabel 1. Karakteristik Responden Umur Pasien Di Rumah Sakit Umum Sundari Medan Tahun 2019.

\begin{tabular}{clcc}
\hline No & \multicolumn{1}{c}{ Umur } & \multicolumn{2}{c}{ Jumlah } \\
\cline { 3 - 4 } & f & \% \\
\hline 1 & $\begin{array}{l}\text { Remaja (17-25 } \\
\text { Tahun) }\end{array}$ & 9 & 22 \\
2 & $\begin{array}{l}\text { Dewasa (26-45 } \\
\text { Tahun) }\end{array}$ & 18 & 43.9 \\
3 & $\begin{array}{l}\text { Lansia (>46 } \\
\text { Tahun) }\end{array}$ & 14 & 34.1 \\
\hline \multicolumn{1}{c}{ Total } & $\mathbf{4 1}$ & $\mathbf{1 0 0}$ \\
\hline
\end{tabular}

Berdasarkan tabel 1 diatas, karakteristik responden yang berjumlah 41 responden (100\%), yang masa remaja berjumlah 9 responden (22\%), sedangkan karakteristik responden yang masa dewasa berjumlah 18 responden (43.9\%), dan karakteristik responden yang masa lansia berjumlah 14 responden (34.1\%) (Iman, 2017).

Tabel 2 Karakteristik Responden Jenis Klamin Pasien Di Rumah Sakit Umum Sundari Medan Tahun 2019.

\begin{tabular}{cccc}
\hline No & \multirow{2}{*}{ Jenis Klamin } & \multicolumn{2}{c}{ Jumlah } \\
\cline { 3 - 4 } & & f & \% \\
\hline 1 & Laki-Laki & 24 & 58.5 \\
2 & Perempuan & 17 & 41.5 \\
\hline \multicolumn{2}{c}{ Total } & $\mathbf{4 1}$ & $\mathbf{1 0 0}$ \\
\hline & & &
\end{tabular}

Berdasarkan tabel 2 karakteristik responden yang berjumlah 41 responden $(100 \%)$, yang berjenis kelamin laki-laki berjumlah 24 responden $(58.5 \%)$, dan karakteristik responden yang berjenis kelamin perempuan berjumlah 17 responden $(41.5 \%)$
Tabel 3. Karakteristik Responden Pendididkan Pasien Di Rumah Sakit Umum Sundari Medan Tahun 2019.

\begin{tabular}{|c|c|c|c|}
\hline \multirow[t]{2}{*}{ No } & \multirow[t]{2}{*}{ Pendidikan } & \multicolumn{2}{|c|}{ Jumlah } \\
\hline & & $\mathbf{f}$ & $\%$ \\
\hline 1 & SD & 14 & 34.1 \\
\hline 2 & SMP & 9 & 22 \\
\hline 3 & SMA & 14 & 34.1 \\
\hline 4 & S1 & 4 & 9.8 \\
\hline & Total & 41 & 100 \\
\hline
\end{tabular}

Berdasarkan tabel 3 karakteristik responden yang berjumlah 41 responden (100\%), yang berpendidikan SD berjumlah 14 responden (34.1\%), sedangkan karakteristik responden yang berpendidikan SMP berjumlah 9 responden (22\%), sedangkan karakteristik responden yang berpendidikan SMA berjumlah 14 responden (34.1\%), dan karakteristik responden yang berpendidikan $\mathrm{S} 1$ berjumlah 4 responden $(9.8 \%)$.

\section{Analisa Univariat}

Tabel 4. Distribusi Frekuensi Pola Makan Responden Di Rumah Sakit Umum Sundari Medan Tahun 2019.

\begin{tabular}{cccc}
\hline \multirow{2}{*}{ No } & Pola Manan & \multicolumn{2}{c}{ Jumlah } \\
\cline { 3 - 4 } & & f & \% \\
\hline 1 & Tidak Teratur & 9 & 22 \\
2 & Teratur & 32 & 78 \\
\hline & Total & $\mathbf{4 1}$ & $\mathbf{1 0 0}$ \\
\hline
\end{tabular}

Berdasarkan tabel 4 dapat diketahui bahwa 41 responden di Rumah Sakit Umum Sundari Medan Tahun 2019 dengan pola makan tidak teratur berjumlah 9 responden (22\%), sedangkan pola makan yang teratur berjumlah 32 responden (78\%).

Table 5. Distribusi Frekuensi Tingkat Stres Responden Di Rumah Sakit Umum Sundari Medan Tahun 2019.

\begin{tabular}{clcc}
\hline No & \multirow{2}{*}{ Tingkat Stres } & \multicolumn{2}{c}{ Jumlah } \\
\cline { 3 - 4 } & & f & $\mathbf{\%}$ \\
\hline 1 & Berat & 16 & 39 \\
2 & Sedang & 21 & 51.2 \\
3 & Ringan & 4 & 9.8 \\
\hline \multicolumn{2}{r}{ Total } & $\mathbf{4 1}$ & $\mathbf{1 0 0}$ \\
\hline
\end{tabular}


Berdasarkan tabel 5 diketahui bahwa 41 responden di Rumah Sakit Umum Sundari Medan Tahun 2019 dengan tingkat stres berat berjumlah 16 responden (39\%), sedangkan tingkat stres sedang berjumlah 21 responden (51.2\%), dan tingkat stres ringan berjumlah 4 responden $(9.8 \%)$.

Tabel 6. Distribusi Frekuensi Kejadian Dispepsia Di Rumah Sakit Umum Sundari Medan Tahun 2019.

\begin{tabular}{|c|c|c|c|}
\hline \multirow[t]{2}{*}{ No } & \multirow{2}{*}{$\begin{array}{c}\text { Kejadian } \\
\text { Dispepsia }\end{array}$} & \multicolumn{2}{|c|}{ Jumlah } \\
\hline & & f & $\%$ \\
\hline 1 & Kronis & 21 & 51.2 \\
\hline 2 & Akut & 20 & 48.8 \\
\hline & Total & 41 & 100 \\
\hline
\end{tabular}

Berdasarkan tabel 6 diketahui bahwa 41 responden di Rumah Sakit Umum Sundari Medan Tahun 2019 dengan kejadian dispepsia kronis berjumlah 21 responden $(51.2 \%)$, dan kejadian dispepsia akut berjumlah 20 responden (48.8\%).

\section{Analisa Bivariat}

Analisa bivariat berguna untuk mengetahui kemaknaan Hubungan Pola Makan Dan Tingkat Stres Dengan Kejadian Dispepsia Di Rumah Sakit Umum Susndari Medan Tahun 2019.

Tabel 7. Hubungan Pola Makan Dengan Kejadian Dispepsia Di Rumah Sakit Umum Sundari Medan Tahun 2019.

\begin{tabular}{clccccccc}
\hline & & \multicolumn{3}{c}{ Kejadian Dispepsia } & Jumlah & Sig \\
\cline { 3 - 6 } No & Pola & \multicolumn{2}{c}{ Kronis } & \multicolumn{2}{c}{ Akut } & & \\
\cline { 2 - 6 } & Makan & f & $\mathbf{\%}$ & $\mathbf{f}$ & $\mathbf{\%}$ & $\mathbf{f}$ & $\mathbf{\%}$ & \\
\hline 1 & Tidak & 8 & 19,5 & 1 & 2,4 & 9 & 22 & 0,020 \\
& Teratur & & & & & & & \\
2 & Teratur & 13 & 31,7 & 19 & 46,3 & 32 & 78 & \\
\hline & Total & $\mathbf{2 1}$ & $\mathbf{5 1 , 2}$ & $\mathbf{2 0}$ & $\mathbf{4 8 , 8}$ & $\mathbf{4 1}$ & $\mathbf{1 0 0}$ & \\
\hline
\end{tabular}

Berdasarkan tabel 7 dapat dilihat tabulasi silang antara pola makan dengan kejadian dispepsia di Rumah Sakit Umum Sundari Tahun 2019 berjumlah 41 responden $(100 \%)$. Diantaranya, pola makan yang tidak teratur berjumlah 9 responden (22\%), kejadian dispepsia yang kronis berjumlah 8 responden $(19,5 \%)$, dan kejadian dispepsia yang akut berjumlah 1 responden (2.4\%).
Sedangkan pola makan yang teratur berjumlah 32 responden (78\%), kejadian dispepsia yang kronis berjumlah 13 responden $(31.8 \%)$, dan kejadian dispepsia yang akut berjumlah 19 responden $(46.3 \%)$.

Berdasarkan hasil statistik uji chisquare pada tingkat kepercayaan 95\% dengan nilai $\alpha=0,05$ diperoleh nilai $p=$ $0,020<$ dari $\alpha=0,05$. Maka diperoleh ada hubungan pola makan dengan kejadian dispepsia di Rumah Sakit Umum Sundari Medan Tahun 2019.

Tabel 8. Hubungan Tingkat Stres Dengan Kejadian Dispepsia Di Rumah Sakit Umum Sundari Medan Tahun 2019.

\begin{tabular}{|c|c|c|c|c|c|c|c|c|}
\hline \multirow{3}{*}{ No } & \multicolumn{5}{|c|}{ Kejadian Dispepsia } & \multicolumn{3}{|c|}{ Jumlah Sig } \\
\hline & \multirow{2}{*}{$\begin{array}{l}\text { Tingkat } \\
\text { Stres }\end{array}$} & \multicolumn{2}{|c|}{ Kronis } & \multicolumn{2}{|c|}{ Akut } & \multirow[b]{2}{*}{$\mathbf{f}$} & \multirow[b]{2}{*}{$\%$} & \multirow{4}{*}{0,038} \\
\hline & & $\mathbf{f}$ & $\%$ & f & $\%$ & & & \\
\hline 1 & Berat & 7 & 17,1 & 9 & 22 & 16 & 39 & \\
\hline 2 & Sedang & 14 & 34,1 & 7 & 17,1 & 21 & 51,2 & \\
\hline \multirow[t]{2}{*}{3} & Ringan & 0 & 0 & 4 & 9,8 & 4 & 9,8 & \\
\hline & Total & 21 & 51,2 & 20 & 48,8 & 41 & 100 & \\
\hline
\end{tabular}

Berdasarkan tabel 7 dapat dilihat tabulasi silang antara tingkat stres dengan kejadian dispepsia di Rumah Sakit Umum Sundari Tahun 2019 berjumlah 41 responden (100\%). Diantaranya, tingkat stres yang berat berjumlah 16 responden (39\%), kejadian dispepsia yang kronis berjumlah 7 responden (17.1\%), dan kejadian dispepsia yang akut berjumlah 9 responden (22\%). Sedangkan tingkat stres yang sedang berjumlah 21 responden $(51.2 \%)$, kejadian dispepsia yang kronis berjumlah 14 responden (34.1\%), dan kejadian dispepsia yang akut berjumlah 7 responden $(17.1 \%)$, dan tingkat stres yang ringan berjumlah 4 responden $(9.8 \%)$, kejadian dispepsia yang kronis tidak ada responden dan kejadian dispepsia yang akut berjumlah 4 responden $(9.8 \%)$.

Berdasarkan hasil statistik uji chisquare pada tingkat kepercayaan 95\% dengan nilai $\alpha=0,05$ diperoleh nilai $p=$ $0,038<$ dari $\alpha=0,05$. Maka diperoleh ada hubungan tingkat stres dengan kejadian dispepsia di Rumah Sakit Umum Sundari Medan Tahun 2019. 


\section{PEMBAHASAN}

\section{Distribusi Frekuensi Pola Makan}

Berdasarkan distribusi frekuensi pola makanyang diketahui bahwa 41 responden (100\%) di Rumah Sakit Umum Sundari Medan Tahun 2019 dengan pola makan tidak teratur berjumlah 9 responden $(22.0 \%)$, sedangkan pola makan yang teratur berjumlah 32 responden (78.0\%).

Kehidupan modern di identik dengan pola makan yang kurang sesuai dengan apa yang dibutuhkan oleh tubuh. Beberapa orang suka berlebihan, memasukkan semua makanan kedalam tubuh tanpa kontrol. Namun, beberapa orang lainnya memperketat asupan makanannya, sehingga tubuh kadangkala kekurangan gizi. Dua hal yang bertolak belakang, namun sering terjadi pada kehidupan sehari-hari (Haryono, 2012).

Pola makan teratur adalah Makan tepat waktu dan teratur sangat penting untuk dilakukan dan bahkan harus dibiasakan. Sebab, makan tepat waktu dan teratur memberikan mamfaat yang luar biasa bagi tubuh. Karenanya, jangan sepelekan waktu makan dan diantara waktu makan yang paling sering diabaikan adalah sarapan. Tidak hanaya masalah melewatkan waktu makan, waktu makan yang tidak tepat waktu dan tidak teratur juga dapat mengakibatkan dampak buruk bagi kesehatan anda. Sebab, makan yang tidak teratur dapatmenyebabkan terjadinya masalah terhadap insulin. Dalam hal ini, profil insulin anda akan menjadi kurang baik (Mardalena, 2018).

Pola makan yang tidak teratur, Seperti diketahui bahwa penyebab penyakit maag yang paling utama adalah makan tidak teratur dan tidak tepat waktu. Misalnya, terlalu siang makan padahal tanpa sarapan di pagi harinya atau mungkin sering makan satu kali dalam sehari atau makan hingga menunggu waktu perut lapar. Kondisi ini tidak hanya dapat menyebabkan timbulnya penyakit maag namun juga memicu kambuhnya penyakit tersebut. Maka dari itu, pola makan yang teratur dan tepat waktu adalah pola makan yang teratur dan tepat waktu adalah pola makan yang dapat mengatasi kemungkinan terserang penyakit ini. Apalagi, maag yang sudah parah bisa mengakibatkan kematian.

Hubungan penyakit maag dengan pola makan yang buruk, Penyakit maag atau yang juga di kenal dengan tukak lambung adalah gejala penyakit pada lambung karena terjadi luka atau peradangan pada organ tersebut dalam hal ini, mukosa (selaput lender yang melapisi lambung) robek karena serangan asam lambung. Pola makan yang tidak teratur membuat lambung sulit untuk beradaptasi. Jika ini berlangsung dalam jangka waktu yang lama, produksi asam lambung akan berlebihan sehingga dapat mengiritasi dinding mukosa lambung. Hal ini yang memyebabkan timbulnya rasa perih dan mual (Mardalena, 2018).

Pola makan adalah Susunan jenis dan jumlah makanan yang di konsumsi seseorang atau kelompok orang pada waktu tertentu terdiri dari frekuensi makan, jenis makanan, dan porsi makan. Kebiasaan makan adalah istilah yang digunakan untuk menggambarkan prilaku yang berhubungan dengan pola makan yang teratur dan tidak teratur yang dapat mempengaruhi resiko terjadinya dispepsia. Dispepsia dapat dipengaruhi oleh beberapa faktor, diantaranya adalah meningkatnya sekresi asam lambung, faktor diet dan lingkungan, serta faktor psikologi seperti stress (Perwitasari, 2016).

Menurut asumsi peneliti berdasarkan penelitian yang dilakukan di Rumah Sakit Umum Sundari Medan Tahun 2019 dapat diketahui bahwa pola makan yang teratur dapat mencegah terjadinya dispepsia dan pola makan yang tidak teratur dapat menyebabkan kejadian dispepsia atau terjadinya kekambuhan dispepsia, untuk itu sangat dianjurkan untuk menjaga pola makan yang teratur.

\section{Distribusi Frekuensi Tingkat Stres}

Berdasarkan Distribusi Frekuensi yang diketahui bahwa 41 responden (100\%) di Rumah Sakit Umum Sundari Medan Tahun 2019 dengan tingkat stres berat berjumlah 16 responden (39\%), sedangkan 
tingkat stres sedang berjumlah 21 responden (51.2\%), dan tingkat stres ringan berjumlah 4 responden $(9.8 \%)$.

Stres dalam arti secara umum adalah perasaan tertekan, cemas, dan tegang. Dalam bahasa sehari-hari stres di kenal sebagai stimulis atau respon yang menuntut individuuntuk melakukan penyesuaian. Serafino mengartikan stres alalah kondisi yang di sebabkan olehinteraksi antara individu dengan lingkungan, menimbulkan persepsi jarak antara tuntutan-tuntutan yang berasal dari situasi yang bersumber pada sistem biologis, psikologis dan sosisal seseorang (Ariwibowo, 2012).

Seseorang yang terkena stres memiliki pola makan yang berubah. Bisa tidak nafsu makan atau malah meningkat nafsu makannya. Hal tersebut sebenarnya terlebih untuk mengalihkan persoalan yang tengah dihadapi. Pola makan yang berubah ini tentu saja sangat mengganggu pola hidup orang tersebut. Berbagai penyakit tak segan menghampiri, mulai dai maag karena tidak nafsu makan sampai mual karena kebanyakan makan. Kalau hal tersebut berlangsung dalam jangka waktu yang lama, dapat dipastikan berbagai permasalahan lainnya akan turut menghampiri kita (Ariwibowo, 2012).

Stres merupakan respon tubuh yang sifatnya non spesifik terhadap setiap tuntutan beban atasnya. Stres yaitu mengacu pada pristiwa yang dirasakan membahayakan kesejahteraan fisik dan psikologis seseorang. Stres memiliki efek negatif melalui mekanisme neuroendokrin terhadap saluran pencernaan sehingga beresiko untuk mengalami dispepsia. Produksi asam lambung akan meningkat pada keadaan stres, misalnya pada beban kerja berat dan tergesagesa/panik. Kadar asam lambung yang meningkat, apabila dibiarkan dapat mengakibatkan terjadinya dyspepsia (Widiya, 2017).

Menurut asumsi peneliti berdasarkan penelitian yang dilakukan di Rumah Sakit Umum Sundari Medan Tahun 2019 dapat diketahui bahwa tingkat stres yang berat, sedang, dan ringan dapat menyebabkan kejadian dispepsia.

\section{Distribusi Frekuensi Kejadian Dispepsia}

Berdasarkan Distribusi Frekuensi yang diketahui bahwa 41 responden (100\%) di Rumah Sakit Umum Sundari Medan Tahun 2019 dengan kejadian dispepsia kronis berjumlah 21 responden (51.2\%), dan kejadian dispepsia akut berjumlah 20 responden $(48.8 \%)$.

Dispepsia adalah rasa nyeri atau tidak nyaman di bagian ulu hati. Kondisi ini dianggap gangguan di dalam tubuh yang diakibatkan reaksi tubuh terhadap lingkungan sekeliling. Reaksi ini menimbulkan gangguan ketidakseimbangan metabolisme, dan sering kali menyerang individu usia produktif, yakni usia 30-59 tahun.

Dispepsia adalah Merupakan kumpulan gejala berupa keluhan nyeri, pearasaan tidak enak pada saluran cerna bagian atas, disertai dengan keluhan seperti rasa penuh saat makan, cepat kenyang, kembung, anoreksia, mual dan muntah. Berbagai mekanisme yang mungkin mendasari meliputi gangguan motilitas usus, hipersensitivitas, infeksi, ataupun faktor psikososial. Walaupun tidak fatal, gangguan ini dapat menurunkan kualitas hidup dan menjadi beban sosial masyarakat (Purnamasari, 2017).

Menurut asumsi peneliti berdasarkan penelitian yang dilakukan di Rumah Sakit Umum Sundari Medan Tahun 2019 dapat diketahui bahwa yang paling banyak jumlah responden yang mengalami kejadian dispepsia kronis berjumlah 21 responden $(52.1 \%)$, dan kejadian dispepsia akut berjumlah 20 responden (48.8\%).

\section{Hubungan Pola Makan Dengan Kejadian Dispepsia Di Rumah Sakit Umum Sundari Medan Tahun 2019}

Berdasarkan tabulasi silang antara pola makan dengan kejadian dispepsia di Rumah Sakit Umum Sundari Tahun 2019 berjumlah 41 responden (100\%). Diantaranya, pola makan yang tidak teratur berjumlah 9 responden (22\%), kejadian 
dispepsia yang kronis berjumlah 8 responden $(19,5 \%)$, dan kejadian dispepsia yang akut berjumlah 1 responden (2.4\%). Sedangkan pola makan yang teratur berjumlah 32 responden $(78 \%)$, kejadian dispepsia yang kronis berjumlah 13 responden (31.8\%), dan kejadian dispepsia yang akut berjumlah 19 responden (46.3\%).

Berdasarkan hasil statistik uji chisquare pada tingkat kepercayaan $95 \%$ dengan nilai $\alpha=0,05$ diperoleh nilai $p=$ $0,020<$ dari $\alpha=0,05$. Maka diperoleh ada hubungan pola makan dengan kejadian dispepsia di Rumah Sakit Umum Sundari Medan Tahun 2019.

Penelitian ini sejalan dengan penelitian yang dilakukan oleh Inri Milly Sorongan, yang berjudul Hubungan Antara Pola Makan Dengan Kejadian Sindroma Dispepsia Pada Siswa-Siswi Kelas XI Di SMA Negeri 1 Manado. Penelitian ini menggunakan analitik cross sectional, responden penelitian berjumlah 220 siswasiswi ditentukan dengan metode purposive sampling yang telah memenuhi sarat dan sudah menendatangani persetujuan. Analisa data menggunakan statistik chi Square. Peneliti memperoleh responden pola makan tidak teratur yaitu 135 orang $(61,4 \%)$. Angka kejadian dispepsia yang positif yaitu 115 orang (52,3\%). Hasil analisa data menunjukkan nilai 0,009 probabilitas lebih kecil dari $0,05(0,009<0,05)$. Artinya terdapat ada hubungan anatara pola makan dengan kejadian sindroma dispepsia pada siswa-siswi kelas XI di SMA Negeri 1 Manado (Sorongan, 2013).

Pola makan adalah susunan jenis dan jumlah makanan yang di konsumsi seseorang atau sekelompok orang pada waktu tertentu terdiri dari frekuensi makan, jenis makanan, dan porsi makan. Menu seimbang perlu dimulai dan dikenal dengan baik sehingga akan berbentuk kebiasaan di kemudian hari. Jumlah dan frekuensi makan perlu di perhatikan untuk meringankan pekerjaan saluran pencernaan dimana sebaiknya makan tiga kali sehari dalam porsi kecil. Jenis makanan perlu juga diperhatikan agar tidak merusak lapisan mukosa lambung. Kebiasaan makan adalah istilah yang digunakan untuk menggambarkan pola makan yang teratur dan tidak teratur yang dapat mempengaruhi resiko terjadinya dispepsia.

Perubahan pola makan yang tidak teratur, obat-obatan yang tidak jelas, zat-zat seperti nikotin dan alkohol serta adanya kondisi kejiwaan stres, pemasukan makanan menjadi kurang sehingga lambung akan kosong, kekosongan lambung dapat mengakibatkan erosi pada lambung akibat gesekan antara dinding-dinding lambung. Kondisi demikian dapat mengakibatkan peningkatan produksi HCL yang akan merangsang terjadinya kondisi asam pada lambung sehingga rangsangan di medulla oblongata membawa impuls muntah sehingga intake tidak adekuat baik makanan maupun cairan (Afifah, 2018).

Hubungan penyakit maag dengan pola makan yang buruk, Penyakit maag atau yang juga di kenal dengan tukak lambung adalah gejala penyakit pada lambung karena terjadi luka atau peradangan pada organ tersebut dalam hal ini, mukosa (selaput lender yang melapisi lambung) robek karena serangan asam lambung. Pola makan yang tidak teratur membuat lambung sulit untuk beradaptasi. Jika ini berlangsung dalam jangka waktu yang lama, produksi asam lambung akan berlebihan sehingga dapat mengiritasi dinding mukosa lambung. Hal ini yang memyebabkan timbulnya rasa perih dan mual. Dispepsia dapat dipengaruhi oleh beberapa faktor, diantaranya adalah meningkatnya sekresi asam lambung, faktor diet dan lingkungan, serta faktor psikologi seperti stres (Mardalena, 2018).

Berdasarkan penelitian ini yang berjudul Hubungan Pola Makan Dan Tingkat Stres Dengan Kejadian Dispepsia Di Rumah Sakit Umum Sundari Medan Tahun 2019. Dapat disimpulkan bahwa pola makan yang teratur dan pola makan yang tidak teratur sangat berpengaruh terhadap tingkat keasaman lambung. Pola makan yang teratur sangat kecil kemungkinan untuk timbulnya dispepsia baik itu akut maupun kronis dan pola makan yang tidak teratur sangat beresiko untuk terjadinya dispepsia atau 
kekambuhan dispepsia. Untuk menjaga timbulnya atau kambuhnya dispepsia sebaiknya lebih diperhatikan lagi pola makan yang teratur dan jenis makanannya.

\section{Hubungan Tingkat Stres Dengan Kejadian Dispepsia Di Rumah Sakit Umum Sundari Medan Tahun 2019}

Berdasarkan tabulasi silang antara tingkat stres dengan kejadian dispepsia di Rumah Sakit Umum Sundari Tahun 2019 berjumlah 41 responden (100\%). Diantaranya, tingkat stres yang berat berjumlah 16 responden (39\%), kejadian dispepsia yang kronis berjumlah 7 responden (17.1\%), dan kejadian dispepsia yang akut berjumlah 9 responden (22\%). Sedangkan tingkat stres yang sedang berjumlah 21 responden $(51.2 \%)$, kejadian dispepsia yang kronis berjumlah 14 responden (34.1\%), dan kejadian dispepsia yang akut berjumlah 7 responden $(17.1 \%)$, dan tingkat stres yang ringan berjumlah 4 responden $(9.8 \%)$, kejadian dispepsia yang kronis tidak ada responden dan kejadian dispepsia yang akut berjumlah 4 responden $(9.8 \%)$.

Berdasarkan hasil statistik uji chisquare pada tingkat kepercayaan $95 \%$ dengan nilai $\alpha=0,05$ diperoleh nilai $p=$ $0,038<$ dari $\alpha=0,05$. Maka diperoleh ada hubungan tingkat stres dengan kejadian dispepsia di Rumah Sakit Umum Sundari Medan Tahun 2019.

Penelitian ini sejalan dengan penelitian yang dilakukan oleh Nurul Afifah dan Ruhyana, yang berjudul Hubungan Tingkat Stres Dan Pola Makan Dengan Kejadian Sindroma Dispepsia Pada Mahasiswa Ilmu Keperawatan Semester Delapan Universitas Aisyiyah Yogyakarta, tingkat stres katagori sedang $(37,2 \%)$ dan hasil uji chi-square hubungan tingkat stres dengan kejadian sindroma dispepsia di peroleh $p$ (0,002)maka dapat di simpulkan bahwa Ada Hubungan Tingkat Stres Dengan Kejadian Sindroma Dispepsia Pada Mahsiswa Ilmu Keperawatan Semester Delapan Universitas Aisyiyah Yogyakarta (Tiana, 2017).

Seseorang yang terkena stres memiliki pola makan yang berubah. Bisa tidak nafsu makan atau malah meningkat nafsu makannya. Hal tersebut sebenarnya terlebih untuk mengalihkan persoalan yang tengah dihadapi. Pola makan yang berubah ini tentu saja sangat mengganggu pola hidup orang tersebut. Berbagai penyakit tak segan menghampiri, mulai dai maag karena tidak nafsu makan sampai mual karena kebanyakan makan. Kalau hal tersebut berlangsung dalam jangka waktu yang lama, dapat dipastikan berbagai permasalahan lainnya akan turut menghampiri kita (Ariwibowo, 2012).

Stres yang terjadi pada setiap individu akan memiliki perbedaan, dimana hal ini dipengaruhi oleh beberapa faktor seperti fungsi fisiologis, kepribadian, karakteristik perilaku dan karakteristik stressor yang dialami dimana mencakup durasi, intensitas, jumlah, cakupan, dan sifat stressor itu sendiri (Hasibuan, 2019). Stres merupakan respon tubuh yang sifatnya non spesifik terhadap setiap tuntutan beban atasnya. Stres yaitu mengacu pada peristiwa yang dirasakan membahayakan kesejahteraan fisik dan psikologis seseorang. Stres memiliki efek negatif melalui mekanisme neuroendokrin terhadap saluran pencernaan sehingga beresiko untuk mengalami dispepsia. Produksi asam lambung akan meningkat pada keadaan stres, misalnya pada beban kerja berat dan tergesa-gesa/panik. Kadar asam lambung yang meningkat, apabila dibiarkan dapat mengakibatkan terjadinya dispepsia (Widiya, 2017).

Berdasarkan penelitian ini yang berjudul Hubungan Pola Makan Dan Tingkat Stres Dengan Kejadian Dispepsia Di Rumah Sakit Umum Sundari Medan Tahun 2019. Dapat disimpulkan bahwa tingkat stres yang ringan, sedang dan berat dapat menimbulkan dispepsia dikarenakan stres memiliki efek negatif melalui mekanisme neuroendokrin terhadap saluran pencernaan sehingga beresiko untuk mengalami dispepsia akut atau kronis. Untuk menjaga timbulnya atau kekambuhan dispepsia sebaiknya mengurangi stres yang berlebihan. 


\section{KESIMPULAN}

Setelah melaksanakan penelitian di Rumah Sakit Umum Sundari Medan Tahun 2019, maka penulis mengambil kesimpulan:

1. Berdasarkan data dan penelitian yang diperoleh dari Rumah Sakit Umum Sundari Medan Tahun 2019 sebanyak 41 responden (100\%), mayoritas pola makan tidak teratur berjumlah 9 responden (22\%), sedangkan pola makan yang teratur berjumlah 32 responden $(78 \%)$.

2. Berdasarkan data dan penelitian yang diperoleh dari Rumah Sakit Umum Sundari Medan Tahun 2019 sebanyak 41 responden $(100 \%)$, mayoritas tingkat stres berat berjumlah 16 responden $(39 \%)$, sedangkan tingkat stres sedang berjumlah 21 responden $(51.2 \%)$, dan tingkat stres ringan berjumlah 4 responden $(9.8 \%)$.

3. Berdasarkan data dan penelitian yang diperoleh dari Rumah Sakit Umum Sundari Medan Tahun 2019 sebanyak 41 responden $(100 \%)$, mayoritas kejadian dispepsia kronis berjumlah 21 responden $(51.2 \%)$, dan kejadian dispepsia akut berjumlah 20 responden (48.8\%).

4. Berdasarkan data dan penelitian yang diperoleh dari Rumah Sakit Umum Sundari Medan Tahun 2019 sebanyak 41 responden (100\%), hasil statistik uji chisquare pada tingkat kepercayaan 95\% dengan nilai $\alpha=0,05$ diperoleh nilai $p=$ $0,020<$ dari $\alpha=0,05$. Maka diperoleh ada hubungan pola makan dengan kejadian dispepsia di Rumah Sakit Umum Sundari Medan Tahun 2019. dan tingkat stres dengan kejadian dispepsia nilai $\alpha=0,05$ diperoleh nilai $p=0,038<$ dari $\alpha=0,05$. Maka diperoleh ada hubungan tingkat stres dengan kejadian dispepsia di Rumah Sakit Umum Sundari Medan Tahun 2019.

\section{SARAN}

1. Bagi Responden

Sebagai sumber pengetahuan bagi responden tentang pentingnya menjaga pola makan yang teratur dan mengendalikan stres dengan baik. Sehinggga kejadian dispepsia menurun di
Rumah Sakit Umum Sundari Medan Tahun 2019.

2. Bagi Tempat Penelitian

Sebagai bahan masukan dan evaluasi terhadap orang-orang yang berada di lingkungan Rumah Sakit Umum Sundari Medan Tahun 2019.

3. Bagi Akademi Keperawatan Helvetian

Sebagai informasi, pengatahuan tambahan dan masukan kepada mahasiswa/i, khususnya pada Keperawatan Medikal Bedah.

4. Bagi Peneliti Selanjutnya

Sebagai acuan dan tambahan refrensi dan wawasan serta pengalaman secara tidak langsung dan dapat digunakan untuk penelitian selanjutnya, yang tertarik dengan judul Hubungan Pola Makan Dan Tingkat Stres Dengan Kejadian Dispepsia Di Rumah Sakit Umum Sundari Medan Tahun 2019.

\section{REFERENSI}

Afifah, N. (2018). Hubungan tingkat stres dan pola makan dengan kejadian sindrom dispepsia pada mahasiswa ilmu keperawatan semester delapan universitas aisyiyah yogkakarta. Skripsi. 2018 juli;(tingkat stres, pola makan, sindrma dispepsia).

Aribowo, T. (2012). Rahasia sehat setiap hari. Jakarta Timur: Dunia Sehat.

Haryono, R. (20120). Keperawatan medikal bedah sistem pencernaan. Cetakan pertama ed. Sleman-yogyakarta: Gosyen Publishing; 2012.

Hasibuan, M. T. D. (2019). Hubungan stres belajar dengan motivasi belajar pada mahasiswa yang menjalani pendidikan di sekolah tinggi ilmu kesehatan murni teguh. Indonesian trust health journal, vol.2, no.1, agustus 2019. ISSN p : 2620-5564, e :2655-1292.

Hutasuhut. (2019). Profil RSU Sundari Medan Medan.

Iman, M. (2016). Panduan penyusunan karya tulis ilmiah bidang kesehatan menggunakan metode penelitian 
ilmiah : cetakan keenam ed. Bandung : citapustaka media printis.

Iman, M. (2017). Pemamfaatan SPSS dalam penelitian bidang kesehatan dan umum. Bandung : Cita pustaka media perintis.

Jaji. (2016). Pengaruh pendidikan kesehatan tentang dispepsia terhadap pengetahuan pekerja penenun songket di desa muara panimbung ulu. Jurnal keperawatan sriwijaya. januari; 3. nomor 1 ISSN No 23555459.

Mardalena, I. (2018). Asuhan keperawatan pada pasien dengan gangguan sistem pencernaan. Yogyakarta: Pustaka Baru Press.

Perwitasari, DT. (2016). Faktor-faktor yang mempengaruhi tingkatan stres pada tenaga kesehatan di RS universitas tanjungpura pontianak tahun 2015 . Jurnal cerebellum. 2016 agustus; 2.nomor 3 .

Purnamasari, L. (2017). Faktor resiko, klasifikasi dan terapi sindroma dispepsia. Continuing medikal education, CDK-259. 2017; 44 NO. 12(dispepsia, functional dispepsia, dispepsia organik).

Putri, RN. (2015). Gambaran sindroma dispepsia fungsional pada mahasiswa fakultas kedokteran universitas riau ankatan 2014. JOM FK. 2015 Oktober; 2 No. 2 (syndroma dyspepsia, FFQ, food consumptsion and risk drinking habbit).

Sorongan, IM. (2013). Hubungan antara pola makan dengan kejadian sindroma didpepsia pada siswa-siswi kelas XI di sma negeri 1 manado. ejournal keperawatan (e-Kp). 2013 agustus; 1. nomor 1 (pola makan, sindroma didpepsia).

Tiana, A. (2017). Hubungan antara sindroma dispepsia dengan pola makan dan jenis kelamin pada mahasiswa fakultas kedokteran universitas kristen krida wancana angkatan 2013. Jurnal kedokteran meditek. 2017 september; 23 No. 63(sindroma dispepsia fungsional, pola makan, jenis kelamin, mahasiswa).

Tilong, AD. (2014). Rahasia pola makan sehat. cetakan pertama ed. Jakarta selatan: FlashBooks.

Widiya, T. (2017). Hubungan pola Makan dan Tingkat stres terhadap kekambuhan gastritis di wilayah kerja puskesmas tarok kota payakumbuh tahun 2017. Jurnal kesehatan andalas http://jurnal.fk.unand.ac.id. 2018 Jul; 2 (pola makan, tingkat stres,kekambuhan gastritis di peskesmas tarok). 